\title{
TINJAUAN TEOLOGIS TENTANG \\ ARTI BERKAT DALAM KEHIDUPAN ORANG PERCAYA
}

\author{
Finilon \\ sttjaffraymakassar@yahoo.co.id \\ I Ketut Enoh
}

\begin{abstract}
ABSTRAK
Finilon Tinjauan, Teologis Tentang Arti Berkat Dalam Kehidupan Orang Percaya.

Tujuan Penulisan Sesuai dengan permasalahan yang diamati, maka tujuan penulisan karya ilmiah ini adalah: Pertama, untuk mengetahui latar belakang pemahaman orang percaya khususnya, dan dunia pada umumnya tentang arti berkat berdasarkan Alkitab. Kedua, untuk menyingkapkan arti berkat yang sesungguhnya, sehingga orang percaya memiliki pemahaman yang benar tentang arti berkat. Ketiga, supaya pembaca karya ilmiah ini dapat menghargai atau mensyukuri setiap berkat yang Tuhan beri dalam kehidupannya.

Dalam penulisan karya ilmiah ini, penulis menggunakan metode penelitian literatur (library research), dan penelitian lapangan (field research) serta menulis hasilnya secara deskriptif.

Berdasarkan hasil uraian penulis tentang arti berkat dalam kehidupan orang percaya, maka penulis dapat menarik kesimpulan sebagai berikut: Pertama, masih banyak orang percaya yang belum memahami berkat sebagai sesuatu yang indah dan menyenangkan dari Tuhan. Kedua, ketidakmampuan orang percaya bersyukur atas berkat Tuhan lebih disebabkan karena kurang memahami bahwa berkat itu berasal dari Tuhan. Sehingga ada juga yang beranggapan bahwa Tuhan tidak memberi berkat kepada manusia, tetapi manusialah yang mengusahakannya bagi dirinya sendiri. Ketiga, kurangnya kesadaran orang percaya bahwa berkat itu berasal dari Allah, banyak dipengaruhi oleh pandangan-pandangan dunia sekuler dan beberapa kelompok Kristen, yang keliru.
\end{abstract}

Kata Kunci: Tinjauan Teologis, Berkat, Kehidupan Orang Percaya 


\section{PENDAHULUAN}

\section{Latar Belakang Masalah}

Hidup adalah perjuangan. Berjuang melawan kerasnya kehidupan, berjuang untuk mendapatkan apa yang diinginkan, bahkan berjuang untuk melawan tantangan zaman. Dunia sekuler bahkan tidak menutup kemungkinan kalangan kelompok kristen pun berjuang keras untuk memperoleh harta bendah yang berlimpah, karena mereka beranggapan bahwa dengan memiliki harta yang melimpah kehidupan ini menjadi lebih muda. Selain hidup menjadi lebih muda, dengan memiliki harta yang berlimpah juga membuat manusia menjadi terhormat, dihargai oleh banyak orang, dan perkataan-perkataannya selalu didengar. Berbeda dengan orang miskin (miskin akan harta benda), kurang dihargai atau bahkan tidak dihargai sama sekali, sebagaimana yang dikatakan oleh Took Hammond: Tidak seorangpun yang mau mendengarkan seorang yang miskin, meskipun mungkin seorang miskin memiliki hikmat, orang-orang tidak akan percaya akan hal itu, sebab bila ia benar-benar cerdas mengapa ia tetap miskin. ${ }^{1}$

Pemahaman yang lain tentang harta yang melimpah adalah merupakan bukti bahwa seseorang diberkati Tuhan. Di kalangan teologi sukses pun berkembang pendapat, bahwa hidup yang diberkati Tuhan adalah hidup yang kaya, berkelimpahan, dan tidak kurang suatu apa pun. ${ }^{2}$ Jake Barnett menilai hal tersebut sebagai "praduga Kristen" yang mungkin tidak sesuai dengan ajaran Alkitab. ${ }^{3}$

Praduga di atas banyak mempengaruhi pemikiran orang percaya dan juga pemimpin-pemimpin gereja tentang berkat. Dalam berbagai percakapan atau pemberitaan Firman, berkat merupakan topik yang sangat menyenangkan, dan tiap orang punya antusias tersendiri bila mendengar perbincangan tentang berkat.

Setiap orang, tidak peduli apa latar belakang agama atau kebudayaannya, mendambakan hidup yang penuh dengan berkat. Berdasarkan pengamatan penulis, setiap agama mempunyai ajarannya sendiri yang harus ditaati oleh penganutnya agar mendapat berkat. Di dalam kekristenan pun tidak terkecuali. Dalam kitab Ulangan 7:12 ; 28:114, diuraikan tentang berkat-berkat yang akan diterima oleh setiap orang yang taat pada Firman Allah, dan masih banyak berkat-berkat lain yang juga diuraikan dalam Alkitab.

\footnotetext{
${ }^{1}$ Took Hammond, Kunci Kekayaan (Light Publishing, 2005), 56.

${ }^{2}$ Herlianto, Teologi Sukses Antara Allah dan Mamon (Jakarta: BPK Gunung Mulia, 1993), 119.

${ }^{3}$ Jake Barnett, Harta dan Hikmat (Bandung: Kalam Hidup), 29-30.
} 
Pemahaman tentang berkat sangatlah luas. Namun, kerap kali orang salah memahaminya, sehingga terperangkap dalam konteks yang salah, akibatnya sangat merugikan, karena orang hanya melihat berkat itu dalam kaidah yang sempit dan terbatas, sehingga tidak sedikit injil sejati telah diubah menjadi injil kemakmuran. ${ }^{4}$

Berdasarkan pengamatan penulis, kebanyakan dari kesaksiankesaksian orang percaya baik yang dimuat dalam majalah atau tabloid maupun yang didengar langsung (melalui dialog atau melalui kesaksian mingguan di gereja), hanya seputar materi, bagaimana Tuhan memberkati usahanya melalui laba yang sangat besar, atau bagaimana Tuhan memperbaiki perekonomian sebuah keluarga. Dan umumnya, orang percaya jika ditanya soal berkat, yang langsung muncul dibenaknya ialah materi (uang atau harta benda). Seolah-olah berkatberkat dari Tuhan hanya sebatas materi, namun arti berkat yang sesungguhnya tidak sedangkal itu.

Melihat kondisi yang demikian, penulis tertarik menulis karya ilmiah dengan judul: "TINJAUAN TEOLOGIS TENTANG ARTI BERKAT DALAM KEHIDUPAN ORANG PERCAYA".

\section{Masalah Pokok}

Dengan melihat latar belakang di atas, maka yang menjadi pokok permasalahan dalam karya ilmiah ini adalah bagaimanakah arti berkat yang sebenarnya berdasarkan Alkitab.

\section{Tujuan Penulisan}

Sesuai dengan permasalahan yang diamati, maka tujuan penulisan karya ilmiah ini adalah: Pertama, untuk mengetahui latar belakang pemahaman orang percaya khususnya, dan dunia pada umumnya tentang arti berkat berdasarkan Alkitab. Kedua, untuk menyingkapkan arti berkat yang sesungguhnya, sehingga orang percaya memiliki pemahaman yang benar tentang arti berkat.

Ketiga, supaya pembaca karya ilmiah ini dapat menghargai atau mensyukuri setiap berkat yang Tuhan beri dalam kehidupannya.

\section{Manfaat Penulisan}

Adapun manfaat dari penulisan karya ilmiah ini adalah sebagai berikut: Pertama, bermanfaat untuk menambah wawasan dan pemahaman pembaca tentang arti berkat. Kedua, sebagai sarana untuk, memberi masukan dan koreksi terhadap cara pandang yang keliru mengenai konsep berkat dalam kehidupan orang percaya. Ketiga, sebagai

${ }^{4}$ Gilbert Lumoindong, Hidup dalam Berkat Allah (Yogyakarta: ANDI, 2000), xi-xii. 
bahan masukan bagi penulis sendiri dalam pelayanan di masa mendatang. Keempat, untuk memenuhi salah satu persyaratan dalam menyelesaikan program studi strata satu (Sl) di Sekolah Tinggi Filsafat Theologia Jaffray Makassar.

\section{Metode Penelitian}

Dalam penulisan karya ilmiah ini, penulis menggunakan metode penelitian literatur (library research), dan penelitian lapangan (field research) serta menulis hasilnya secara deskriptif.

\section{BERKAT DALAM PENDEKATAN KONSEPTUAL BAGI KEHIDUPAN}

\section{Definisi Berkat}

Kamus Besar Bahasa Indonesia, memberikan empat definisi dari berkat. Pertama, karunia Tuhan yang membawa kebaikan dalam hidup manusia. Kedua, doa restu dan pengaruh baik (dari orang-orang yang dihormati). Ketiga, makanan dan lain sebagainya yang dibawa pulang sehabis kenduri. Keempat, mendatangkan kebaikan; bermanfaat; berkah. ${ }^{5}$

Kamus Umum Bahasa Indonesia, memberikan dua definisi dari berkat. Pertama, apa yang diterima manusia dari Tuhan (harta, kesehatan, kebahagiaan, rezeki dan lain sebagainya untuk kehidupan). Kedua, sedekah; selamatan (di Sunda). ${ }^{6}$

Kamus Webster's, mendefinisikan berkat sebagai one who blesses; a benediction; a means of happiness or walfare; a beneficent gift; in analogous or devired senses. ${ }^{7}$

Bagi Gilbert Lumoindong, berkat (dalam pemahaman yang luas) merupakan segala sesuatu yang disediakan Allah bagi manusia. Tidak ada batasan antara orang baik atau jahat, Allah tetap menyediakan matahari, atau sumber air, udara dan sebagainya. ${ }^{8}$

Dalam Perjanjian Lama kata berkat berasal dari kata Barak, to bless. Dan dalam bentuk kata kerja diberkati/memberkati adalah berakah, katakata ini muncul dalam Alkitab sebanyak 415 kali. Dari 415 kali

\footnotetext{
${ }^{5}$ Kamus Besar Bahasa Indonesia., s.v. "berkat".

${ }^{6}$ Kamus Umum Bahasa Indonesia., s.v. "berkat". "blessing".

${ }^{7}$ W.T. Harris. Webster's New International Dictionary (By: G \& C. Merriam Co), s.v.

${ }^{8}$ Gilbert Lumoindong. Hidup dalam Berkat Allah (Yogyakarta: Yayasan ANDI, 2000), xii.
} 
penggunaan kata tersebut, 214 di antaranya diterjemahkan dengan kata berkat.

Kedua kata ini memiliki pengertian yang dalam dan bervariasi. Kata barak atau berakah diterjemahkan dan dirumuskan sebagai berikut : berkat, keuntungan, kedamaian, kebahagiaan dan segala yang baik. Kedua kata ini diaplikasikan secara atau sebagai pengalaman yang holistik, utuh, dan menyeluruh pada kondisi manusia dan alam ciptaan Allah.

Dekarya ilmiah nya adlah bahwa kata barak atau berakah meliputi seluruh aspek kehidupan manusia, baik aspek fisik: dalam hal kesehatan dan kekuatan, apek ekonomi: dalah hal kelimpahan materi, aspek sosial: dalam hal hubungan yag harmonis dengan sesama manusia, dan aspek spiritual: dalam hal hidup yang tenang, damai dengan yang Mahatinggi.

Kata barak atau berakah biasanya dalam konteks Alkitab merupakan suatu tindakan dari yang tertinggi kedudukan atau posisinya kepada yang rendah atau bawahannya. Dalam Alkitab tentu dari Allah kepada manusia atau tepatnya dari Allah kepada umat-Nya. Dapat juga merupakan tinddakan dari orang tua kepada anak temurunya. Umumya dalam bentu ucapan.

Dalam Perjanjian Baru, kata berkat berasal dari kata eulogeo. Kata ini merupaka sebuah kata jadian. Eulogeo berasal dari kata eu yamg artinya baik dan lego yang artinya perkataan, ucapan.

Kata benda eulogeo dalam penggunaannya menjadi kata kerja eulogia - blessing mengandung pengertian suatu ucapan dari dewa (dalam konteks Yunani) yang dilanjutkan dengan suatu aksi yang nyata yang mendatangkan rejeki atau keuntungan fisik, ekonomi, sosial, dan spiritual.

Dlam kontek Alkitab, ini berarti suatu bentuk penyataan atau pewahyuan dari Allah kepada umat-Nya tentang berkat, keuntungan, kenyamanan, dan damai. Dan ucapan tersebut dinyatakan dalam sebuah aksi Yang nyata.

Jadi kata berkat, diberkati, dan memberkati dirumuskan sebagai suatu tindakan Allah dalam kedaulatan dan kasih-Nya mewahyukan melalui pekataan dan aksinya suatu kondisi yang penuh kelimpahan, kesehatan, keuntungan, dan kedamaian pada umat-Nya.

\section{Berkat Keselamatan}

Pada umumnya manusia memandang keselamatan sebagai suatu keadaan dimana jiwa seseorang bebas atau terlapas dari siksaan api neraka. Namun dalam kekristenan, keselamatan berarti suatu keadaan di mana manusia yang seharusnya dihulum mati sebagai akibat dari dosa- 
dosanya, digantikan oleh Yesus Kristus sehingga manusia beroleh hidup yang kekal.

Jadi, keselamatan berkaitan erat dengan dosa. dr. R Soedarmo mengatakan "Akan tetapi pernyataan jatuhnya manusia adalah permulaan dari keselamatan kita. Pengakuan tentang keadaan dosa yang rill (nyata) menjadi jalan untuk mencari kelepasan dari dosa". ${ }^{9}$ Manusia adalah gambar dan rupa Allah, namun karena dosa, maka gambar itu menjadi rusak. Rasul Paulus mengatakan bahwa semua manusia telah berbuat dosa dan telah kehilangan kemuliaan Allah (Roma 3:23). Dosa menjadikan manusia sebagai seteru Allah dan ujpa dosa adalah maut (Roma 6:23a). Allah sanat mengasihi manusia sekalipun manusia telah berdosa. Allah tidak ingin manusiua dihukum mati, untuk itu Ia mengutus Anak-Nya yang tunggal datang ke dunia dan menjadi penebus dosa pengganti manusia.

Dari sudut pandang Allah, keselamatan meliputi segenap karya Allah dalam membawa manusia keluar dari hukuman menuju pembenaran, dari kematian ke kehidupan yang kekal, dari musuh (seteru) menjadi anak. Dari sudut pandang manusia, keselamatan mencakup segala berkat yang berada di dalam Kristus, yang bisa diperoleh dalam kehidupan sekarang maupun kehidupan yang akan datang. ${ }^{10}$

Setiap orang yang dilahirkan kedalam dunia ini tidak dapat berbuat sesuatu unutk mendapatkan anugrah keselamatan dari Allah. Kerusakan tidak berarti bahwa manusia tidak dapat melakukan perbuatan yang baik menurut pandangan manusia maupun Allah. Tetapi kerusakan sesungguhnya berarti bahwa karena seluruh keberadaan telah menjadi rusak, maka manusia tidak pernah dapat melakukan sesuatu untuk bisa mendapat anugrah keselamatan dari Allah. Dalam hubungannya dengan keselamatan, hal ini berrti bahwa pertolongan harus datang dari seseorang yang tidak dipengaruhi oleh kerusakan itu, seorang yang tidak berdosa sama sekali.

Pribadi yang terlibat dalam korban penebusan itu, yang tidak berdosa sama sekali ialah Allah yang menjelma menjadi manusia. Hannya pribadi inilah yang dapat menyelamatkan umat manusia. Charles C. Ryrie mengatakan, "Hanya Allah - Manusia (tidak ada duanya dalam sepanjang sejarah) yang memenuhi syarat untuk menjadi juruselamat sejati. Juruselamat itu haruslah manusia agar dapat mati. Dan juruselamat itu harus Allah, supaya dapat menjadikan kematian itu sabagai pembayaran lunas atas dosa. Apabila seorang yang berdosa mati,

\footnotetext{
${ }^{9}$ R. Soedarmo. Ikhtisar Dogmatika (Jakarta: BPK Gunung Mulia, 1985), 120.

${ }^{10}$ Charles C. Ryrie. Teologi Dasar 2 (Yogyakarta: ANDI, 2006), 15.
} 
ia mati bagi dosanya sendiri. Sorang pribadi yang tidak berdosa sama sekali dapat menebus dosa-dosa orang lain". ${ }^{11}$

Meskipun keselamatan dalam Kristus ditawarkan secara universal, namun tidak semua orang yang ada di dunia akan diselamatkan seperti yang tertulis dalam Injil Matius 22:14 "Sebab banyak yang terpanggil, tetapi sedikit yang dipilih". Hanya orang-orang pilihan (dipilih oleh Allah untuk diselamatkan) saja yang akan selamat. Keselamatan dalam Kristus juga diberi secara cuma-cuma. Artinya, keselamatan adalah anugrah Allah bagi manusia dan manusia tidak perlu melakukan suatu pekerjaan agar memperoleh keselamatan itun (Efesus 2:8-9).

Jadi, keselamatan yang ada di dalam Kristus adalah berkat dari Allah. Dan ini adladh berkat terbesar dari semua berkat yang Tuhan beri kepada manusia.

\section{Berkat Damai Sejahtera}

Damai sejahtera terdiri dari 2 kata, yakni damai dan sejahtera. Menurut Kamus Besar Bahasa Indonesia damai adalah: "tentram; tenang; keadaan tidak bermusuhan; rukun; dan aman."12 Sedangkan sejahtera, masih menurut Kamus Besar Bahasa Indonesia, adalah, "aman sentosa dan makmur; selamat."13 Jadi, damai sejahtera adalah suatu keadaan yang tentram, damai, dan tenang, tanpa ada perasaan khawatir ataupun takut.

Keadaan yang damai dan tenang, dimana pertengkaran dan pertikaian tak pernah terjadi, merupakan pola kehidupan yang didambakan oleh setiap orang. Dalam kehidupan kekristenan pun terjadi. Banyak orang Kristen senang yang mendengar khotbah-khotbah yang bersifat penghiburan. Keadaan yang demikian banyak dimanfaatkan oleh pengkhotbah-pengkhotbah yang mengejar kesuksesan (kelimpahan materi). Tidak jarang adanya nubuat-nubuat atau penglihatan-penglihatan yang lebih merupakan hasil rekaan dari manusia dan bukan sesuatu yang dinyatakan oleh Tuhan. Mereka senang menghibut umat dengan damai sejahtera yang semu, memberikan harapan yang kosong (sia-sia) dan hiburan keselamatan. ${ }^{14}$ khotbahkhotbah maupun buku-buku yang menjelaskan hal demikian, sangat disenangi, karena berisi penghiburan tentang suatu keadaan yang penuh damai sejahtera, sekalipun sifatnya itu semu.

Dunia bahkan banyak dari orang Kristen pun menganggap kekayaan atau kelimpahan materi sebagai ukuran kehidupan yang damai

\footnotetext{
${ }^{11}$ Ibid., 23.

${ }^{12}$ Kamus Besar Bahasa Indonesia, s.v. đamai"

${ }^{13}$ Ibid., s.v. "sejahtera"

${ }^{14}$ Herlianto, Teologia Sukses antara Allah dan Mamon (Jakarta: BPK Gunung Mulia, 1993), 160.
} 
dan sejahtera. Keyakinan itulah yang mendorong umat untuk terus bekerja agar kehidupan yang limpah dengan harta benda, menjadi pola hidup mereka. Tujunnya ialah untuk kebahagiaan mereka. Ketika umat manusia memperoleh segalanya, mereka tersadar bahwa harta benda tidak dapat memberikan damai sejahtera separti yang mereka dambakan, jika kehidupan mereka jauh dari Tuhan.

Damai sejagtera atau kebahagiaan sejati, hanya ada di dalam Kistus. Dunia dapat memberikan damai sejahtera, namun sifatnya semu (Yoh. 14:27). Setiap orang yang telah menerimah Kristus sebagai juruselamat pribadi, dituntun untuk menghasilakan buah-buah Roh dalam kehidupannya. Salah satu dari buah-buah Roh ialah, damai sejahtera (Gal. 5:22). Damai sejahtera itu tidak dicari-cari, melainkan hasil dari kehidupan yang dipimpin oleh Roh Kudus. Tidak ada alasan untuk orang percaya untuk tidak merasa damai dii dalam kehidupannya, jika ia benar-benar hidup di bawah pimpinan Roh Kudus, karena kehidupan yang dipimpin oleh Roh Kudus akan menghasilakn buah, yakni damai sejahtera. Dan hal itu hanya dimiliki oleh orang yang telah lahir baru.

Jadi, damai sejahtera adalah berkat dari Tuhan kepada umat-Nya. Disaat dunia berusaha mencarinya umat Allah justru memperolehnya secara cuma-cuma. Yakni ketika umat Allah menyerahkan seluruh totalitas kehidupannya dan berjalan dibawah pimpinan Roh Kudus, sehingga kehidupannya menghasilkan buah-buah Roh.

\section{Berkat Harta Benda}

Dalam Kamus Besar Bahasa Indonesia, harta benda adalah barang kekayaan. ${ }^{15}$ Jadi, dapat dikatakan bahwa harta benda adalah barangbarang berharga yang dimiliki oleh orang tertentu, yakni orang-orang kaya (secara materi).

Harta benda atau kekayaan secara materi adalah kebutuhan hidup yang diperjuangkan oleh umat manusia dalam kelangsungan hidupnya di dunia ini. Uang mewakili hal-hal materi atau harta benda. Sebagai alat tukar dan penyimpan nilai, uang mempermudah penanganan kita akan harta kekayaan. Jadi uang merupakan satu masalah yang mendasar dan umum bagi manusia. Jake Barnett menyatakan bahwa: "rata-rata lima puluh persen dari hidup kita berhubungan dengan uang." ${ }^{\text {"16 }} \mathrm{Hal}$ ini berarti bahwa, lima puluh persen dari waktu kita, perhatian kita, kekuatan mental kita, emosi kita, percakapan kita, keberhasilan kita, kegagalan kita, masalah kita - berhubungan dengan uang. Itulah sebanya Alkitab begitu banyak berbicara tentang uang: Siapa yang menyediakan

\footnotetext{
${ }^{15}$ Kamus Besar Bahasa Indonesia. S.V. "harta benda".

${ }^{16}$ Jake Barnett. Harta dan Hikmat (Bandung: Kalam Hidup, 1983), 20.
} 
bagi kita, bagaimana cara yang harus kita tempuh untuk mendapatkannya, dan cara yang justru tidak boleh kita tempuh untuk mendapatkannya, masalah-masalah yang timbul berkenaan dengan uang, dan yang paling penting bagaimana seharusnya sikap kita terhadap uang.

Mengapa uang menjadi masalah yang mendasar bagi manusia? Karena uang merupakan kebutuhan umat manusia dan manfaatnya sangat banyak. Weslley Penias mengatakan, "Uang bermanfaat untuk membandingkan sebuah nilai dan sebagai pemberi rasa nyaman, aman, rasa percaya diri. Selain itu juga, uang dapat mengubah atau menukar posisi, misalnya: posisi uang sebagai kerta menjadi gula." ${ }^{\text {,7 }}$

Melihat manfaat uang yang begitu besar dalam kehidupan manusia, maka tak dapat disangkal bahwa ada keinginan dihati manusia untuk memilikinya sebanyak mungkin. Namun banyak juga orang percaya yang menganggap bahwa uang itu jahat. Sebenarnya uang itu tidak jahat, tetepi cinta akan uang yang merupakan akar dari segala kejahatan (1 Timotius 6:10), dan orang yang memiliki uang tidaklah berdosa. Demikian juga dengan orang yang memiliki kekayaan melimpah. Tidak juga berarti bahwa kemiskinan merupakan ciri dari dari kehidupan orang rohani. Segala sesuatu yang ada pada kita adalah pemberian Tuhan. Kekayaan adalah berkat Tuhan, pemberian Tuhan kepada anak-anak-Nya. Kekayaan adalah perwujudan dari kasih Tuhan (Kejadian 24:34-35).

Kekayaan dapat membangun, yaitu disalurkan kepada produktivitas. Tetapi kekayaan juga dapat merusak, yaitu jika diboroskan dengan berpesta pora dan dihabiskan untuk memuaskan hawa nafsu. Jadi jelaslah bahwa kekayaan dapat membangun ataupun merusak, bukan karena sifat kekayaan itu, melainkan karena dosa pemakainya. Masalah yang sebenarnya terletak pada penggunaannya dan pengaturannya, bukan pada bendanya.

Allah mencurahkan berkat-Nya bagi umat manusia dalam bentuk kekayaan, karena Ia tahu bahwa kekayaan diperlukan bagi kelangsungan pekerjaan Tuhan dan untuk kesinambungan hidup manusia. Namun sangat disayangkan ada begitu banyak umat manusia yang menyalahgunakan kekayaan tersebut, sehingga terjebak dalam ketamakan. Kita jarang memandang ketamakan sebagai dosa yang mengerikan. Gary Inrig memandang ketamakan sebagai suatu hasrat yang kuat untuk memiliki lebih banyak lagi dan didalamnya terkandung nuansa keserakahan, nafsu untuk memperoleh sesuatu. ${ }^{18}$ Alkitab memandang ketamakan sama dengan penyembahan berhala (Kolose 3:5).

\footnotetext{
${ }^{17}$ Weslley Penias (dosen STT.J). Catatan Kuliah Teologi Perjanjian Baru. STT Jaffray Makassar, 15 Mei 2008.

${ }^{18}$ Gary Inrig. Bijak Mengelolah Uang (Yogyakarta: Yayasan Gloria, 1998), 13.
} 
Kalau ketamakan sama dengan penyembahan berhala, itu berarti orang yang tamak menjadikan berkat Tuhan (kekayaan) sebagai berhala. Dan ini sangat menyimpang dari tujuan Allah memberkati umat-Nya.

Allah memberkati umat-Nya dalam bentuk kekayaan, tidak berarti bahwa orang yang hidup dalam kemiskinan tidak diberkati. Banyak orang berpikir bahwa Allah tidak menginginkan adanya kemiskinan sehingga semua orang percaya harus menjadi kaya. Kita dapat menemukan jawaban dalam Alkitab tentang alasan mengapa ada orang percaya yang hidup dalam kemiskinan.

Amsal 10:4, menjelaskan bahwa tangan yang lamban (malas) mendatangkan kemiskinan. Ayat ini berlaku secara umum baik untuk orang percaya atau bukan. Orang malas, mempunyai angan-angan atau mimpi namun tidak pernah terwujud karena mereka selalu menunda. Ini adalah alasan pertama mengapa ada orang percaya yang miskin.

Alasan kedua, hidup yang dikuasai nafsu. Amsal 23:20-21, menjelaskan tentang keadaan seseorang yang hidupnya dikuasai oleh nafsu, apa pun yang dimilikinya tidak bisa menjadi berkat bagi dirinya. Tidak akan pernah ada kepuasan. Orang yang dikuasai nafsu akan menjadi miskin karena hawa nafsu tersebut membuatnya tidak dapat menikmati segala berkat Tuhan.

Alasan yang ketiga, sedang dalam proses. Allah memproses kita karena Ia ingin mencabut kesombongan yang merupakan penghambat berkat Tuhan dan untuk mencabut keegoisan kita. Namun yang pasti, Allah turut bekerja sama untuk mendatangkan kebaikan. ${ }^{19}$ Seperti kisah Ayub.

Baik miskin atau kaya, adalah berkat Tuhan. Walau pun kita hidup dalam kemiskinan namun kalau bebas dan tidak tertindas, maka kita adalah orang kaya. Semikian sebaliknya dengan orang kaya. Walaupun hidupnya berlimpah harta, namun mereka tidak bebas bahkan tertindas, mereka disebut juga sebagai orang miskin. Kaya atau miskin bukanlah suatu ukuran hidup yang diberkati Tuhan. Tetapi kebebasan dan kepuasan dalam menikmati semua yang ada pada kita menjadi ukuran kehidupan yang diberkati Tuhan.

\section{Berkat Kesehatan Fisik}

Kebanyakan umat Kristen, khususnya penganut teologi sukses. Mereka menganggap kesembuhan sempurna dan bebas dari berbagai sakit penyakit merupakan tanda kesuksesan seseorang, sehingga orang-

\footnotetext{
${ }^{19}$ Roma 8:28.
} 
orang yang terkena sakit penyakit dianggap sebagai orang yang sakit rohani atau tidak beriman. ${ }^{20}$

Pelayanan yang dilakukan oleh Yesus Kristus untuk menyembuhkan orang-orang yang sakit jasmani dapat kita lihat dalam kitab-kitab Injil. Jenis-jenis penyakit (jasmani) yang disembuhkan oleh Yesus bermacam-macam dengan penyebab yang berbeda pula. Banyak orang yang beranggapan bahwa sakit penyakit disebabkan oleh dosa dan iblis. Memang benar dalam Alkitab disebutkan bahwa dosa dapat mengakibatkan sakit penyakit (Matius 9:1-8) dan iblis juga dapat membuat seseorang menjadi sakit. Tapi dalam Alkitab juga disebutkan penyebab yang lain. Jadi tidak semua sakit penyakit disebabkan oleh dosa atau iblis. Kadangkala Allah mengijinkan seseorang menderita sakit penyakit karena Allah mau menyatakan pekerjaan-pekerjaan-Nya melalui orang tersebut.

Waktu Yesus sedang lewat, Ia melihat seorang yang buta sejak lahirnya. Murid-murid-Nya bertanya kepada-Nya: "Rabi, siapakah yang berbuat dosa, orang ini sendiri atau orang tuanya, sehingga ia dilahirkan buta?" Jawab Yesus: "Bukan dia dan bukan juga orang tuanya, tetapi karena pekerjaan-pekerjaan Allah harus dinyatakan di dalam dia. (Yohanes 9:1-3).

Dari ayat di atas kita melihat bahwa tidak ada sangkut pautnya ajaran dosa dengan kebutaan orang itu dan kebutaan itu hanya merupakan cacat alamiah.

Kesehatan jasmani (fisik) adalah berkat Tuhan yang kadangkala dianggap sepele sehingga jarang orang yang mengucap syukur kepada Tuhan atas kesehatan jasmaninya. Ada banyak orang yang memiliki harta melimpah namun tidak dapat menikmati kekayaannya karena menderita sakit penyakit. Mereka hidup dengan berbagai macam larangan dokter.

Dengan kondisi tubuh yang sehat, kita dapat melakukan apa saja. Kita dapat menikmati berkat-berkat lain yang Tuhan berikan. Dengan kondisi tubuh yang vit/sehat kita dapat melakukan tanggung jawab dengan baik. Selain itu, kondisi tubuh yang sehat juga memampukan kita untuk melayani Tuhan. Jeremia Djadi menegaskan bahwa: "Apabila seorang gembala sering-sering sakit, tentu ia tidak akan dapat melayani Tuhan secara maksimal. Agar gembala jemaat dapat melayani Tuhan dengan baik, disamping memelihara kesehatan rohani, ia juga harus menjaga dan memelihara kesehatan tubuhnya."21

\footnotetext{
${ }^{20}$ Herlianto. Teologi Sukses Antara Allah dan Mamon (Jakarta: BPK Gunung Mulia, 2006), 169.

${ }^{21}$ Jeremia Djadi (dosen STT J). Diktat Pelayanan Pastoral (Makassar: STT Jaffray Makassar, 2007), 10.
} 
Jadi, kesehatan (fisik) adalah berkat Tuhan. Tapi bukan berarti orang yang menderita sakit penyakit tidak diberkati Tuhan. Yohanes 9:13, dengan jelas kita lihat bahwa terkadang Allah memakai sakit penyakit untuk menyatakan kehendak-Nya. Kita juga dapat melihat kisah Ayub, yang diizinkan oleh Allah untuk ditimpahi suatu penyakit sejenis kusta. Allah mengijinkan hal itu menimpa Ayub karena Allah ingin menunjukkan kepada iblis bahwa Ayub adalah seorang saleh. Hal ini ditegaskan oleh C Bijl, dengan mengatakan: "Tapi justru karena terbukti "mungkin" dan "mampu" Tuhan mempercayai Ayub, Tuhan menerima tantangan iblis. Sebab Dia tahu, Anak-Nya akan berhasil membawa manusia kembali kepada-Nya." ${ }^{22}$

Sekalipun Yesus Kristus telah menebus kita dari dosa, Tuhan tidak akan menghilangkan penyakit dan penderitaan dari kehidupan orang percaya. Artinya, orang percaya dapat saja mengalami sakit penyakit sama seperti orang-orang yang belum percaya.

\section{Fungsi Berkat}

Dalam Kamus Besar Bahasa Indonesia, fungsi berarti kegunaan suatu hal. ${ }^{23}$ Dapat dikatakan bahwa fungsi adalah kegunaan atau manfaat dari suatu hal, baik itu hal-hal yang abstrak atau non abstrak.

Segala sesuatu yang ada di muka bumi ini mempunyai fungsi atau kegunaan, baik fungsi secara positif maupun secara negatif. Segala sesuatu berfungsi secara positif atau negatif tergantung pada si pemakai (yang menggunakan). Demikian halnya dengan berkat. Berkat yang Tuhan beri dapat berfungsi secara positif maupun negatif, tergantung pada manusia yang menerimanya (memakainya).

Dalam karya ilmiah ini, penulis hanya membahas fungsi berkat secara positif . secara umum berkat berfungsi sebagai:

Pertama, untuk kemuliaan Tuhan. Segala sesuatu yang dimiliki oleh orang percaya adalah merupakan sarana yang dapat dipakai bagi kemuliaan Tuhan. Amsal 3:9 "muliakanlah TUHAN denga segala hartamu dan dengan hasil pertama dari segala penghasilanmu". Pelayanan harta benda adalah bagian dari ibadah kepada Tuhan. Allah dihormati bila umat Allah mempersembahkan harta miliknya kepadaNya.

Persembahan yang berkenan di hadapan Tuhan adalah member dengan sukacita dan dengan kerelaan hati. Alasan untuk bersuka cita ialah karena hal itu merupakan kesempatan untuk memberi kepada Tuhan. Pemberian orang percaya kepada Allah adalah suatu perwujudan ucapan terima kasih kepasa-Nya dan sebagai suatu kesempatan dan hak

\footnotetext{
${ }^{22}$ C. Bijl. Ayub Sang Konglomerat (Jakarta: Yayasan Komunikasi Bina Kasih / OMF, 2004).

${ }^{23}$ Kamus Besar Bahasa Indonesia. S.V "fungsi".
} 
istimewa untuk ambil bagian dalam kelangsungan pekerjaan Tuhan. Memberi bukanlah persoalan apa yang dimiliki orang percaya. Member adalah persoalan hati; member adalah hal pengorbanan yang diberikan kepada Allah. ${ }^{24}$

Jadi, Allah menghendaki agar segala yang dimiliki oleh umatnya dipakai untuk kemuliaan Tuhan, sebab segala yang dimiliki oleh orang percaya adalah pemberian dari Tuhan, oleh Dia, dan kepada Dia, sehingga segala kemuliaan hanya bagi Dia saja sampai selama-lamanya (Roma ll:36).

Kedua, untuk kesejahteraan manusia. Allah memberkati manusia yang mengasihi-Nya dengan mencukupkan segala kebutuhannya. Baik itu tempat tinggal, pakaian, makanan dan minuman, dan lain sebagainya. Jika kita menyimak proses penciptaaan dalam Kejadian Pasal 1, kita dapat melihat bahwa walaupun manusia merupakan ciptaan Allah yang paling mulia dari semua ciptaan-Nya yang lain, manusia tidak diciptakan dihari pertama, melainkan hari keenam (hari terakhir Allah bekerja). Bukan tanpa alasan Allah menciptakan manusia dihari terakhir. Allah ingin agar manusia hidup sejahtera dimana kebutuhan manusia tercukupi. Untuk itu, sebelum menciptakan manusia, Allah menciptakan langit dan bumi sebagai tempat manusia berpijak. Lalu kemudian Allah menciptakan air, tumbuh-tumbuhan, dan hewan. Semuanya itu untuk kesejahteraan manusia.

Ketiga, menjadi saluran berkat. Menjadi saluran berkat berarti Allah memakai kita untuk memberkati orang lain. Berkat yang Allah berikan dalam kehidupan ini bukan untuk kita nikmati sendirian, tetapi Allah mau agar kita juga memberikannya kepada orang yang membutuhkan. Kita dipanggil untuk hidup bagi sesama demi kemulilaan Allah. ${ }^{25}$

Allah memerintahkan kita untuk mengasihi sesama manusia, seperti diri sendiri karena inilah hukum kedua setelah perintah untuk mengasihi Allah dan tidak ada hukum lain yang lebih utama dari pada hukum kedua ini (Markus 12:30-31). Kalau kita mengasihi sesama manusia berarti kita harus menolong yang susah dan membantu mereka yang membutuhkan. Julianto Simanjuntak, mengatakan: "Kita bisa memberi tanpa mencintai, tetapi kita tidak bisa mencintai tanpa memberi." ${ }^{26}$

Mencintai atau mengasihi, membutuhkan pengorbanan (memberi). Berkat yang Allah berikan kepada kita baik itu kekayaan,

\footnotetext{
${ }^{24}$ John Mac Arthur. Memberi Kepada Allah (Jakarta: BPK Gunung Mulia, 1998), 82.

${ }^{25}$ Tulus Tu’u. Makna Penderitaan (Bandung: Kalam Hidup, 1993), 17.

${ }^{26}$ Julianto Simanjuntak. Mencintai Hingga Terluka (Tangerang: Layanan Konseling Keluarga dan Karir, 2006), 68.
} 
makanan dan minuman, pakaian, pengetahuan dapat kita bagikan kepada orang-orang yang membutuhkan, sebagai bukti kasih kita kepada mereka bagi kemuliaan Allah. Ingatlah bahwa kita hidup di dunia ini tidak hanya untuk diri sendiri.

\section{Cara Memperoleh Berkat}

Ada banyak cara yang dilakukan oleh manusia untuk memperoleh berkat. Namun tidak menutup kemungkinan salah satu atau beberapa dari cara tersebut menyimpang dari kebenaran Firman Allah. Berikut ini penulis akan menguraikan dua cara memperoleh berkat yang sesuai dengan Firman Allah.

\section{Melalui Doa}

Menurut Ensiklopedi Alkitab Masa Kini, doa adalah:

Kebaktian mencakup segala sikap roh manusia dalam pendekatannya kepada Allah. Orang Kristen berbakti kepada Allah, jika ia memuja, mengagungkan dan mengajukan permohonan kepada Allah dalam doa. Doa sebagai perbuatan tertinggiyang dapat dilakukan oleh roh manusia, dapat juga dipandang sebagai persekutuan dengan Allah, selama penekanannya diberikan kepada Allah. Seseorang berdoa kepada Allah karena Allha telah menyentuh rohnya. Dalam Alkitab doa bukanlah suatu tanggapan biasa dari manusia tetapi suatu tanggapan yang sungguh-sungguh dari manusia. ${ }^{27}$

Dalam bukunya, J. Wesley Brill dikatakan bahwa doa adalah:

Berhubungan atau berkomunikasi dengan Allah. Doa merupakan pernyataan dari keterangan manusia kepada Allah untuk segala sesuatu. Doa mendatangkan kuasa Allah dalam kehidupan manusia. Tujuan berdoa adalah untuk memuji Allah, mengucap syukur kepada Allah meminta pertolongan dari Allah bagi diri kita dan bagi orang lain. Disaat kita memanjatkan permohonan doa kepada Allah maka kita yang berdoa harus memiliki pengharapan bahwa kita akan menerima dari Tuhan, tanpa berada dalam suatu keragu-raguan. ${ }^{28}$

Dapat disimpulkan bahwa doa adalah ungkapan hati manusia kepada Allah tentang segala hal seperti permohonan, syukur, dan pujian penyembahan. Seorang yang berdoa atau yang meminta kepada Allah berarti ia adalah seorang yang tunduk kepada kehendak Allah dan hidup menurut kehendak Allah. Walaupun seorang yang hidup berkenan kepada Allah berdoa kepada Allha, Allah akan tetap menjawab doa itu

${ }^{27}$ Ensiklopedi Alkitab Masa Kini, Jilid I, s.v. “doa”.

${ }^{28}$ J. Wesley Brill, Doa-doa Dalam Perjanjian Lama (Bandung: Kalam Hidup, n.d.), 1. 
sesuai dengan kehendak-Nya; bukan karena ia berkenan kepada Allah, tetapi karena Allah menyatakan kehendak-Nya ketika ia meminta. Hanya Allah lah yang berhak memutuskan untuk menjawab atau tidak menjawab doa.

Allah memberikan perintah untuk berdoa kepada-Nya bukan berarti Ia tidak mengetahui kebutuhan yang sedang diperlukan. Ia memberikan perintah demi umat-Nya, yaitu hubungan dengan Dia dan hidup menurut kehendak-Nya. Seorang yang mengaku ${ }^{29}$ umat Tuhan berarti hidup dibawah pimpinan dan pengaruh kuat kuasa Roh Kudus yang membawanya melakukan kehendak Allah, yaitu berdoa.

1 Tesalonika 5:17, "Tetaplah berdoa", Allah memberi perintah kepada umat-Nya untuk tetap berdoa. Artinya, apapun yang terjadi umat Allah harus tetap berdoa. Tidak semua doa yang diucapkan oleh umat Allah, langsung dijawab. Tetapi, dengan menyerahkan seluruh pergumulan atau masalah kepada Allah melalui doa, berarti umat Allah percaya bahwa Allah sanggup menolong dan keyakinan itu akan membuat umat Allah kuat melewati setiap tantangan. Roh Kudus sangat berperan dalam doa karena RoKudus membantu menyempurnakan setiap doa yang dinaikkan oleh orang-orang percaya (Roma 8:26).

Jadi, berdoa merupakan cara memperoleh berkat Allah dalam bentuk iman, sehingga umat Allah mampu melewati setiap kerikil dalam kehidupannya dan ini merupakan berkat yang indah.

\section{Dengan Bekerja}

Bekerja merupakan bagian yang harus dipikul oleh setiap orang. Hari demi hari, kebanyakan orang usia produktif menghabiskan waktunya di tempat kerja. Ada yang menjadi pengusaha, ada yang menjadi karyawan. Tidaklah mengherankan jika kehidupan masyarakat sangat dipengaruhi oleh dunia usaha dan oleh segala permasalahannya. Beban yang bernama pekerjaan itu telah mengubah orang menjadi baik atau jahat, jujur atau manipulatif, dermawan atau serakah.

Seringkali orang berpikir bahwa pekerjaan pasti membawa pengaruh yang buruk. Sebagian orang mepercayai bahwa dunia bisnis akan mengubah manusia menjadi lebih duniawi, hanya berorientasi pada keuntungan. Maka ada yang menganggap bahwa bekerja bukanlah pekerjaan yang mulia; seseorang tidak boleh menghabiskan waktunya terlalu banyak di dunia bisnis tanpa diimbangi dengan kegiatan yang bersifat rohani. Akhirnya, dunia bisnis menjadi area yang terpisah dari

${ }^{29}$ Parel T.J, Karya ilmiah : Teologi Doa dalam Pengajaran Paulus (Makassar: STTJ Makassar,2006), 48. 
dunia rohani. Segala yang ada di dunia bisnis di anggap tidak dapat diatur dan pasti tidak cocok dengan kehidupan spiritual. ${ }^{30}$

Kerja berarti kemuliaan. Keluaran 34:21 memberikam perintah: "Eman hari lamanya engkau bekerja, tetapi pada hari ketujuh haruslah engkau berhenti, dan dalam musim membajak dan musim menuai haruslah engkau memelihara hari perhentian juga." Biasanya tekanan diberikan pada istirahat satu hari dalam seminggu. Tetapi perhatikanlah bahwa ayat ini mengatakan, "Enam hari lamanya engkau bekerja." Itu adalah perintah, bukan pilihan. Kemalasan dikutuk. Setiap orang memberikan sumbangan dalam mendukung keluarganya. Dalam Amsal 3:6-8 Allah memerintahkan umat-Nya untuk mengamati semut dan belajar darinya. Semut bekerja untuk keras untuk mengumpulkan makanan agar dapat terus hidup. Kerja di masa kini mencakup segala sesuatu yang dilakukan untuk melangsungkan kehidupan keluarga, bukan sekedar kerja suatu usaha. Kerja, merupakan bagian penting dalam kehidupan.

"Tetapi jika ada orang yang tidak memelihara sanak saudaranya, apalagi seisi rumahnya, orang itu murtad dan lebih buruk dari orang yang tidak beriman" (1 Timotius 5:8). Ini tanggung jawab besar. Seorang Kristen harus mencukupi kebutuhan fisik keluarganya. Bila tidak, kesaksiannya runtuh. Tekanan yang diberikan disini adalah pada kebutuhan, bukan kemewahan. Dalam masyarakat mana pun, cara pertama untuk mencukupi kebutuhan keluarga dengan adil adalah dengan bekerja.

Jelas Allah Mahakuasa, mampu mencukupi kebutuhan umat-Nya dengan cara apa pun yang ingin Dia berikan: manna, anugrah, pemerintahan, atau apa saja; tetappi pada umumnya kecukupan datang dari bekerja. ${ }^{31}$

Jadi, kerja atau pekerjaan merupakan salah satu sarana selain berdoa, untuk mengalirkan berkat-berkat-Nya kepada umat-Nya.

\footnotetext{
${ }^{30}$ Donny Adi Guna, Tafsir Roma Bagi Pekerja (Yogyakarta: ANDI, 2004), vii.

${ }^{31}$ Jerry dan Mary White, Bekerja: Arti, Tujuan, dan Masalah-masalahnya (Jakarta: BPK Gunung Mulia, 1990), 20.
} 


\section{APLIKASI KONSEP BERKAT \\ BAGI KEHIDUPAN ORANG PERCAYA PADA MASA KINI}

Berkat Sebagai Pemberian Allah Melalui Iman - Dalam Bentuk Keselamatan. Kamus Besar Bahasa Indonesia memberikan definisi tentang iman sebagai "suatu kepercayaan yang berkenaan dengan agama atau keyakinan kepada Allah, nabi, kitab, dan sebagainya." "32 Oxford memberikan definisi iman yaitu: "faith is belief in devine truth without proof." 33 demikian juga Frelig mengatakan, "iman adlkah kepercayaan yang mutlak kepada sesuatu yang dianggap benar, artinya iman melibatkan unsure pengetahuan dalam diri manusia. Namun iman bukan sekedar mempercayai atau mengetahui banyak hal itu, tetapi iman melibatkan unsur kehendak dan unsur perasaan atau emosi. Emosi dan kehendak keduanya bekerjasama dan bersatu dalam mempraktekkan iman". ${ }^{34}$

Di dalam Perjanjian Baru, kata iman berasal dari bahasa Yunani pistis dan serimg dengan kata kerja pisteuo serta kata sifat pistis. Pistis diterjemahkan ke dalam bahasa Indonesia dengan kata iman; kepercayaan; dan keyakinan. Kata kerja pisteuo diterjemahkan dengan kata beriman, percaya terhadap atau kepada Allah dalam Yesus Kristus, sedangkan kata pistis diterjemahkan dengan kata setia. ${ }^{35}$

Dengan demikian, iman pada umumnya diartikan sebagai kepercayaan atau keyakinan kepada sesuatu yang dianggap benar. Iman Kristen adalah kepercayaan yang mutlak kepada Allah melalui Yesus Kristus yang adalah kebenaran. Kebenaran yang sejati adalah Firman Allah, sehingga kebenaran tersebut mutlak ditaati dan diyakini secara utuh.

Iman harus mempunyai isi; harus ada kepercayaan atau keyakinan tentang sesuatu. Mempunyai iman kepada Kristus untuk keselamatan berarti mempunyai keyakinan bahwa Ia dapat menghilangkan kesalahan dosa dan mengaruniakan hidup kekal. Wesley Brill, mengatakan, "Iman yang menyelamatkan yaitu iman kepada Pribadi Juruselamat. Iman yang menyelamatkan ialah penyerahan jiwa yang najis dan berdosa kepada Tuhan serta menyambut Yesus Kristus sebagai sumber pengampunan, kesucian dan kehidupan (Matius 11:28-29; Kisah Para Rasul 16:31; Yohanes 1:12; 20:31; Efesus 3:17; Wahyu 3:20). ${ }^{36}$

\footnotetext{
${ }^{32}$ Kamus Besar Bahasa Indonesia., s.v. "iman”.

33 As Hornbg, Oxford Advanced Learner's Dictionary Of current English (London: University Press, 1987), s.v. "faith".

${ }^{34}$ Harold M. Frelig, Delapan Tiang Keselamatan (Bandung: Kalam Hidup, 1962), 26.

${ }^{35}$ Elvi Tappang, Karya ilmiah : Konsep Kekayaan Kerdasarkan 2 Korintus Pasal 8-9 dan Aplikasinya Bagi Orang Kristen (Makassar: STTJ, 2007), 29.

${ }^{36}$ J. Wesley Brill, Dasar Yang Teguh (Bandung: Kalam Hidup, 2004), 215.
} 
Keselamatan selalu melalui iman, bukan karena iman (Efesus 2:8). Iman adalah terusan yang menjadi bagi manusia untuk memerima karunia hidup kekal dari Allah; hal itu bukanlah sebabnya. Untuk itulah manusia tidak bisa membanggakan diri, sekalipun karena imannya. Tetapi iman diperlukan sebagai jalan satu-satunya (Yohanes 5:24; 17:3). ${ }^{37}$

Ketika manusia jatuh ke dalam dosa, rohnya terpisah dari Allah dan mati (secara rohani). Roh yang mati itu harus dibangkitkan/ dihidupkan melalui kelahiran baru (dilahirkan kembali dalam roh). dr. A. J. Gordon yang dikutip oleh Wesley Brill, menjelaskan tentang kelahiran kembali demikian, "Dilahirkan kembali berarti menerima kodrat ilahi oleh pekerjaan Roh Kudus dengan perantara Firman Allah". ${ }^{38}$ Wesley Brill juaga mengutip perkataan dr. R. A. Torrey yang menerangkan hal itu demikian, "Dalam kelahiran kembali Allah memberikan perangai-Nya yang suci dan berbudi, yaitu perangi yang berpikir seperti Allah (Kolose 3:10), berperasaan seperti Allah dan berkehendak seperti Allah (I Yohanes 3:14; 4:7-8)". ${ }^{39}$

Pertobatan dan iman adalah bagian atau pekerjaan manusia, dan kelahiran kembali adalah bagian atau pekerjaan Allah melalui Roh Kudus di dalam hati manusia. Dan bila ketiga hal itu terjadi dalam diri seseorang, maka ia diselamatkan; ia mendapat hidup yang kekal. Bilamana ia menerimah Tuhan Yesus Kristus, maka Tuhan melakukan hal itu di dalam hatinya. Inilah anugrah dan karya terbesar yang Allah kerjakan dan berikan kepada manusia.

\section{Berkat Sebagai Pemberian Allah Melalui Makanan dan Minuman - Dalam Bentuk Kesehatan Fisik}

Enam puluh persen $(60 \%)$ dari berat tubuh kita terdiri dari air, karena tubuh kita sangat membutuhkan air dalam jumlah yang banyak. Rata-rata setiap hari kita memerlukan air \pm 3 liter. Namun kenyataannya, setiap hari kita biasanya hanya minum \pm 1 liter air. Itu berarti dalam satu tahun kita minum air kira-kira 360 liter. $^{40}$

Pentingnya air bagi kesehatan dapat dilihat dari jumlah air yang ada di dalam organ, seperti, $80 \%$ dari darah terdiri atas air, $25 \%$ dari tulang, $75 \%$ dari urat syaraf, $80 \%$ dari ginjal, $70 \%$ dari hati, dan $75 \%$ dari otot adalah air. Kehilangan air $15 \%$ dari berat tubuh dapat mengakibatkan kematian. Kekurangan air ini menyebabkan banyaknya didapati penyakit batu ginjal dan kandung kemih di daerah tropis

\footnotetext{
${ }^{37}$ Charles C. Ryrie, Teologi Dasar 2 (Yogyakarta: ANDI, 2006), 86.

${ }^{38}$ J. Wesley Brill, Dasar Yang Teguh (Bandung: Kalam Hidup, 2004), 219.

${ }^{39}$ Ibid.

${ }^{40}$ Tulus Tu’u. Kuasa Bersyukur (Bandung: Kalam Hidup, 1998), 15.
} 
seperti Indonesia, karena terjadinya kristalisasi unsur-unsur yang ada di dalam cairan tubuh. ${ }^{41}$

Air merupakan kebutuhan yang sangat vital dalam kehidupan manusia. Air yang kita minum berfungsi sebagai bahan pelarut, membawa segala jenis makanan ke seluruh tubuh dan mengambil kembali segala buangan untuk dikeluarkan dari tubuh. Air juga ikut serta mempertahankan suku badan, karena dengan penguapannya suhu dapat menurun.

Makanan adalah sumber energi satu-satunya bagi manusia. Dari segi kuantitas, baik yang berlebihan maupun yang kekurangan akan menyebabkan kelainan gizi. Penyakit yang berhubungan dengan kegemukan, disebabkan jumlah makanan yang berlebihan, juga kualitasnya seringkali tidak seimbang. Demikian pula yang kekurangan gizi. Ada yang hanya kekurangan kuantitas makanan saja, tetapi seringkali juga kualitasnya kurang.

Jadi makanan dan minuman merupakan kebutuhan yang sangat mendasar bagi kelangsungan hidup manusia. Makanan dan minuman juga sangat berpengaruh bagi kesehatan manusia. Allah senantiasa mencukupi kebutuhan kita akan makanan dan minuman agar kesehatan manusia tetap terjaga. Mungkin tidak semua orang percaya mampu menyediakan gizi yang cukup buat keluarganya, akan tetapi hal itu bukanlah tanda bahwa kita tidak diberkati Tuhan. Alkitab tidak hanya menyebutkan bahwa Tuhan memberkati kita dengan memberikan makanan dan minuman, tetapi Alkitab juga menyebutkan bahwa apa pun yang kita makan dan minum akan diberkati sehingga kita menjadi sehat.

Kesehatan adalah berkat dari Tuhan, melalui makanan dan minuman yang kita konsumsi setiap hari. Namun kalangan teologi membuatnya lebih ekstrim lagi, dengan mengatakan: "Kita orang-orang Kristen dapat menjalani kehidupan di dunia ini dalam keadaan bebas dari segala penyakit ... Penyakit hanyalah merupakan salah satu wujud kutukan Allah." ${ }^{43}$

Kesehatan adalah berkat Tuhan, karena tubuh yang sehat kita dapat melakukan apa saja. Dengan tubuh yang sehat kita akan mampu meraih cita-cita, kita dapat melayani Tuhan secara full, dan sebagainya. Namun bukan berarti seseorang yang menderita sakit penyakit tidak diberkati Tuhan. Atau mungkin, ada seseorang yang menderita sakit

\footnotetext{
${ }^{41}$ Juli Soemirat Slamet. Keschatan Lingkungan (Yogyakarta: Gadjah Mada University Press, 2002), 84.

${ }^{42}$ ibid., 170.

${ }^{43}$ Herlianto. Teologi Sukses Antara Allah dan Mamon (Jakarta: BPK Gunung Mulia, 2006), 171.
} 
penyakit dan sudah sekian lama ia menggumuli penyakitnya tersebut, tetapi kesembuhan tak kunjung datang, malahan kematian yang datang menjemput. Dalam kasus tersebut, kita tidak dapat menvonis orang tersebut dengan tuduhan bahwa orang tersebut tidak diberkati Tuhan karena banyak dosa. Memang ada penyakit yang disebabkan oleh dosa, tetapi tidak semuanya disebabkan oleh dosa. Kita tidak dapat mengetahui dengan pasti apa maksud Tuhan dibalik semua itu, sebab rancangan Tuhan terlebih tinggi (Yesaya 55:9). Namun satu hal yang perlu kita ingat bahwa Allah tidak pernah merancangkan yang jahat bagi kita, tetapi Dia merancangkan damai sejahtera (Yeremia 29:11).

\section{Berkat Sebagai Pemberian Allah Melalui Pekerjaan - Dalam Bentuk Benda}

Hampir separuh dari seluruh kehidupan seseorang dilewati dengan bekerja, karena bekerja merupakan kegiatan yang dilakukan terus menerus oleh manusia. Tanggapan manusia terhadap pekerjaan membentang luas penuh dengan berbagai perasaan dan sikap. Ada orang mungkin mencintai pekerjaan, menghirupnya setiap hari, terdorong untuk melakukan lebih banyak lagi pekerjaan, terpesona oleh segala kemungkinannya, dan bahkan terserap oleh tantangan-tantangannya. Orang ini dapat dikatakan hidup untuk bekerja.

Tetapi kendati ada yang menyukai kerja, ada banyak juga orang lain yang sekedar menerimanya sebagai suatu tuntutan kehidupan, merasakannya sebagi sesuatu yang berat, membosankan dan tidak memuaskan. Mereka bangun pagi dan berangkat kerja dengan enggan, dan sering tunduk kepada atasan-atasan yang mungkin kurang adil, tugas-tugas yang tidak menarik, atau kondisi-kindisi kerja yang tidak manusiawi. Mereka bekerja hanya sekedar untuk mencari nafkah. Seperti yang dikemukakan oleh Suryanto yang bekerja di salah satu mini market yang ada di Makassar:

Bagiku, bekerja itu sangat melelahkan dan menjenuhkan. Ingin rasanya saya berhenti bekerja di tempat ini. Karena pekerjaan yang saya kerjakan setiap harinya tidak sebanding dengan gaji yang saya terima setiap bulannya. Ditambah lagi dengan sikap atasan yang kurang bersahabat, sering marah tanpa alasan yang jelas. Tetapi kalau saya berhenti bekerja, dari mana saya mendapatkan uang? ${ }^{44}$

Ada banyak orang yang memiliki persoalan yang sama dengan Suryanto di atas. Bekerja hanya untuk sekedar mencari nafkah sehingga mereka tidak menikmati pekerjaannya dan akibatnya, mereka tidak mengenal kata "syukur". Dan bahkan yang lebih para dari itu, mereka

\footnotetext{
${ }^{44}$ Suryanto. Percakapan telepon dengan penulis, 26 April 2008.
} 
tidak menganggap pekerjaan itu sebagai berkat dari Tuhan, melainkan kutukan. Hal ini dijelaskan oleh Jerry dan Mary White: "Banyak orang Kristen merasa curiga bahwa kerja adalah lebih merupakan kutuk dari Allah, bukan berkat." ${ }^{45}$ Jhon Stott, menambahkan dengan mengatakan: "Pandangan itu (pandangan ortodoks tentang kerja), mengiakan ajaran Perjanjian Lama yang menyatakan bahwa kerja badani adalah kutuk yang dijatuhkan ke atas manusia akibat dosa-dosanya."

Memang, ada pekerjaan yang oleh kejatuhan manusia berubah menjadi usaha yang penuh jerih payah (bumi terkutuk, dan kultivasi hanya mungkin melalui kerja keras dan cucuran keringat), namun itu pada dirinya adalah konsekuensi diciptakannya kita oleh Allah segambar dengan diri-Nya, Allah sendiri tampil dalam Kejadian 1 sebagai pekerja. Sebelum Allah beristirahat dan memberkati ciptaan-Nya, Ia menciptakan manusia, dan dengan melakukan hal itu membuat manusia juga menjadi pekerja-pekerja sama seperti Dia.

Dalam Perjanjian Lama, kerja amatlah dihormati, khususnya pekerjaan keahlian orang-orang yang mempunyai kemampuan untuk membuat barang-barang seperti tukang perak, pengasah batu, tukang kayu, dan lain sebagainya, amat dihormati. Perjanjian Lama memandang kerja sebagai bagian yang utuh dari kehidupan. Konsep ini muncul dari pandangan yang penuh pengharapan terhadap tanggung jawab kepada keluarga. Kegagalan dalam memenuhi kebutuhan mereka membuat seseorang tersingkir dari masyarakatnya. Setiap anak Yahudi dituntut untuk belajar melakukan pekerjaan manual. Jerry dan Mary White, mencatat:

Bagi seorang Yahudi kerja amatlah penting, karena kerja adalah intisari kehidupan. Orang-orang Yahudi mengenal ungkapan "orang yang tidak mengajar anak lelakinya berusaha, mengajarnya mencuri." Seorang rabi Yahudi sama kedudukannya dengan seorang dosen atau professor di perguruan tinggi, tetapi menurut hukum Yahudi ia tidak boleh menerima satu sen pun dari tugas mengajarnya; ia harus menguasai suatu bidang usaha yang dilakukannya dengan tangannya dan dengan demikian ia memenuhi kebutuhannya sendiri. Karena itu ada rabi yang menjadi tukang jahit, tukang sepatu, tukang cukur atau tukang roti dan bahkan pula menjadi aktor. Bekerja bagi seorang Yahudi adalah kehidupan. ${ }^{47}$

\footnotetext{
${ }^{45}$ Jerry dan Mary White. Bekerja: Arti, Tujuan, dan Masalah-Masalahnya (Jakarta: BPK Gunung Mullia, 1990), 15.

${ }^{46} \mathrm{Jhon}$ Stott. Isu-Isu Global (Jakarta: Yayasan Komunikasi Bina Kasih / OMF, 2005), 214.

${ }^{47}$ Jerry dan Mary White. Bekerja: Arti, Tujuan, dan Masalah-Masalahnya (Jakarta: BPK Gunung Mullia, 1990), 16.
} 
Kitab Amsal penuh dengan peringatan tentang kerja keras. "Orang yang bermalas-malas dalam pekerjaannya sudah menjadi saudara dari si perusak" (8:19). "Kemalasan mendatangkan tidur nyenyak, dan orang yang lamban akan menderita lapar" (19:15). Jadi, Perjanjian Lama mencela kemalasan dan memuji kerja keras. Sedangkan dalam Perjanjian Baru, kerja diasumsikan sebagai cara yang normal bagi kehidupan setiap orang. Tak satupun dari konsep-konsep Perjanjian Lama dibuang, melainkan justru dikuatkan, dengan penekanan tambahan pada sikap orang yang bersangkutan terhadap kerjanya dan majikannya.

Dalam surat Rasul Paulus yang kedua kepada jemaat di Tesalonika, Paulus mengucapkan pernyataan yang keras, dimana seseorang yang tidak bekerja, tidak boleh makan (3:10). Aturan ini berlaku bagi orangorang yang memilih untuk tidak bekerja, yang terlalu malas, terlalu rewel dalam memilih jenis pekerjaan.

Jadi, kerja bukanlah kutuk, melainkan salah satu sarana yang digunakan oleh Allah untuk memberkati kita dalam hal mencukupi kebutuhan financial kita. Tetapi sangat disayangkan karena hanya sedikit orang percaya yang meganggapnya sebagai berkat dari Tuhan. Kaum liberal dan naturalis misalnya. Bagi mereka harta kekayaan yang mereka miliki bukanlah pemberian (berkat) dari Tuhan, melainkan hasil jerih payah mereka sendiri. Mereka bekerja dengan kekuatan mereka sendiri dan dengan pengetahuan mereka sendiri sehingga pekerjaan mereka membuahkan hasil dan itulah yang mereka gunakan untuk mencukupi kebutuhan financial mereka. Weslley Penias mengatakan,

Bagi kaum liberal semua yang mereka miliki adalah merupakan hasil kerja mereka, karena mereka bekerja, maka mereka digaji. Ini logis/ masuk akal dan tidak ada campur tangan Tuhan. Demikian juga dengan kaum naturalis, mereka menganggap semua yang mereka miliki adalah hasil kerja mereka. Mereka menanam pohon pisang dan mengasilkan buah pisang. Hal itu terjadi secara natural (alami), tanpa campur tangan Tuhan. ${ }^{48}$

Alkitab dengan jelas menyatakan bahwa apa yang kita miliki atau kita peroleh di dunia ini adalah pemberian Tuhan (berkat dari Tuhan). Kitab Ulangan 8:17-18, dan Maleakhi 3:11, cukup untuk menjelaskan hal tersebut dan juga untuk menyanggah konsep liberalism dan naturalis.

Ulangan 8:17-18 "Maka janganlah kaukatakan dalam hatimu: Kekuasaanku dan kekuatan tangankulah yang membuat aku

\footnotetext{
${ }^{48}$ Weslley Penias (dosen STT.J). Percakapan telepon dengan penulis, 24 Mei 2008.
} 
memperoleh kekayaan ini. Tetapi haruslah engkau ingat kepada TUHAN, Allahmu, sebab Dialah yang memberikan kepadamu kekuatan untuk memperoleh kekayaan, ... " Sebelum bangsa Israel masuk ke tanah Kanaan, Allah telah mengingatkan mereka agar mereka tidak sombong dengan apa yang mereka miliki dan menganggap bahwa semuanya itu mereka peroleh dengan kekuatan sendiri. Memang benar bahwa kitalah yang bekerja sehingga dapat memeperoleh uang atau kekayaan. Kita menggunakan kekuatan kita sendiri, keahlian kita sendiri, dan bahkan pengetahuan kita sendiri. Tetapi Allalah yang memberikan kekuatan dan kemampuan kepada kita sehingga kita mampu menyelesaikan pekerjaan kita dengan baik. Allah bukan hanya sumber kekuatan tapi juga sumber hikmat. Karena Allah adalah sumber hikmat maka setiap orang yang kekurangan hikmat dapat memintanya kepada Allah (Yakobus 1:5).

Maleakhi 3:1l, "Aku akan menghardik bagimu belalang pelahap, supaya jangan dihabisinya hasil tanahmu dan supaya jangan pohon anggur di padang tidak berbuah bagimu, firman TUHAN semesta alam." Ayat ini dilatar belakangi oleh keadaan orang Israel yang telah menyimpang dari ketetapan-ketetapan TUHAN dan tidak memeliharanya. Bangsa Israel telah menipu Allah mengenai persembahan persepuluhan dan persembahan khusus. Untuk itu Allah menegur mereka dan meminta mereka untuk kembali pada-Nya. Dan Allah berjanji akan memberkati kehidupan mereka dan ladang mereka kalau mereka kembali pada-Nya dan taat kepada-Nya, serta bersikap jujur dalam membawa persembahan persepuluhan.

Dari ayat tersebut, sangatlah jelas bahwa Allahlah yang mengatur alam ini. Memang benar bahwa manusialah yang mengolah lahan (tanah), menanam, merawat dan memelihara apa yang ditanam, tetapi Tuhanlah yang memberkati. Perubahan-perubahan alam diatur oleh Allah. Tuhan dapat menghardik atau membiarkan belalang pelahap, dan Ia juga dapat membuat pohon-pohon berbuah atau tidak. Sekalipun seorang petani merawat tanamannya dengan sebaik mungkin, tetapi jikalau Tuhan tetap membiarkan belalang pelahap menghabiskan hasil tanahnya dan mengutuk pohon-pohon sehingga tidak menghasilkan buah, maka sia-sialah usaha petani tersebut.

Dari dua nats di atas, jelaslah bahwa harta benda yang kita miliki adalah berkat dari Tuhan. Tetapi tidak berarti bahwa harta benda menjadi ukuran seseorang diberkati Tuhan, seperti yang diyakini oleh penganut teologi sukses. Allah memberkati kita dengan mencukupkan kebutuhan finansial kita, tetapi bukan berarti orang percaya yang masih hidup dalam kemiskinan, tidak diberkati tuhan. Ada hukum yang berlaku "yang meminta akan diberi; yang mencari akan mendapatkan; yang mengetok akan dibukakan pintu (Matius 7:7)." Tetapi terkadang 
Allah juga memakai penderitaan atau kemiskinan untuk menyatakan kehendak-Nya.

\section{PENUTUP}

\section{Kesimpulan}

Berdasarkan hasil uraian penulis tentang arti berkat dalam kehidupan orang percaya, maka penulis dapat menarik kesimpulan sebagai berikut: Pertama, masih banyak orang percaya yang belum memahami berkat sebagai sesuatu yang indah dan menyenangkan dari Tuhan. Kedua, ketidakmampuan orang percaya bersyukur atas berkat Tuhan lebih disebabkan karena kurang memahami bahwa berkat itu berasal dari Tuhan. Sehingga ada juga yang beranggapan bahwa Tuhan tidak memberi berkat kepada manusia, tetapi manusialah yang mengusahakannya bagi dirinya sendiri. Ketiga, kurangnya kesadaran orang percaya bahwa berkat itu berasal dari Allah, banyak dipengaruhi oleh pandangan-pandangan dunia sekuler dan beberapa kelompok Kristen, yang keliru. Keempat, banyak orang percaya yang beranggapan bahwa ia diberkati ketika mendapatkan keuntungan yang besar, kekayaan yang melimpah, usahanya lancar, dan sembuh dari sakit. Tanpa menyadari bahwa berkat Allah itu dapat dinikmati setiap hari setiap hari melalui pemeliharaan Allah. Kelima, arti berkat yang sesungguhnya jika dipandang dari segi teologis adalah segala sesuatu yan Allah beri maupun yang Allah izinkan terjadi dalam kehidupan orang percaya. Suka maupun duka, kelimpahan atau kekurangan, semuanya adalah berkat dari Tuhan. Keenam, berkat yang Allah berikan kepada umat-Nya, bukan untuk dinikmati sendiri, tetapi juga dipakai untuk kemuliaan Tuhan dan sebagai sarana untuk menyalurkan berkat Tuhan bagi orang lain. Ketujuh, mengucap syukur dalam segala hal merupakan bukti bahwa seseorang menyadari berkat-berkat Tuhan dalam kehidupannya setiap hari.

\section{Saran-Saran}

Dengan selesainya karya ilmiah ini, penulis memberikan beberapa saran kepada orang percaya dan secara khusus kepada pembaca karya ilmiah ini. Adapun saran-saran yang dapat penulis berikan adalah sebagai berikut: Pertama, hendaknya setiap gereja (pemimpin gereja) memperhatikan pengajarannya (isi khotbah) agar benar-benar sesuai dengan kebenaran Firman Allah, sehingga anggota jemaatnya tidak mudah dipengaruhi oleh ajaran-ajaran dari luar gereja yang mungkin 
kebenarannya sangat diragukan, seperti halnya tentang arti berkat. Banyak orang percaya memperoleh iformasi tentang arti berkat dari sumber yang kurang jelas. Kedua, hendaknya setiap orang percaya dapat meluangkan waktunya setiap hari untuk merenungkan kebenaran Firman Tuhan, sehingga setiap orang percaya memiliki pemahaman yang benar tentang kebenaran Firman Tuhan secara khusus tentang arti berkat. Ketiga, hendaknya setiap pemimpin geraja bersama dengan anggota jemaatnya, tidak langsung menerimah bahkan meyakini setiap ajaran yang masuk ke dalam gereja. Tetapi haruslah diuji kebenarannya terlebih dahulu berdasarkan Firman Tuhan.

Dan akhirnya, penulis sangat mengharapkan agar melalui karya ilmiah ini, dapat menjadi berkat bagi setiap orang percaya.

\section{KEPUSTAKAAN}

Buku-buku

Arthur, John Mac Memberi Kepada Allah. Jakarta: BPK Gunung Mulia, 1998.

Barnett, Jake. Harta dan Hikmat. Bandung: Kalam Hidup, n.p.

Bijl. C.Ayub Sang Konglomerat. Jakarta: Yayasan Komunikasi Bina Kasih / OMF, 2004.

Brill, J. Wesley. Dasar Yang Teguh. Bandung: Kalam Hidup, 2004.

Brill, J. Wesley. Doa-doa Dalam Perjanjian Lama. Bandung: Kalam Hidup, n.d.

Djadi, Jeremia. Diktat Pelayanan Pastoral. Makassar: STT Jaffray Makassar, 2007.

Frelig, Harold M. Delapan Tiang Keselamatan. Bandung: Kalam Hidup, 1962.

Guna, Donny Adi. Tafsir Roma Bagi Pekerja. Yogyakarta: ANDI, 2004.

Hammond, Took. Kunci Kekayaan. Light Publishing, 2005.

Herlianto, Teologi Sukses Antara Allah dan Mamon. Jakarta: BPK Gunung Mulia, 1993.

Hornbg, As. Oxford Advanced Learner's Dictionary Of current English. London: University Press, 1987.

Inrig, Gary. Bijak Mengelolah Uang (Yogyakarta: Yayasan Gloria, 1998), 13.

Jerry dan Mary White. Bekerja: Arti, Tujuan, dan Masalah-Masalahnya. Jakarta: BPK Gunung Mullia, 1990.

J., Parel T. Karya ilmiah : Teologi Doa dalam Pengajaran Paulus. Makassar: STTJ Makassar, 2006. 
Lumoindong, Gilbert. Hidup dalam Berkat Allah. Yogyakarta: ANDI, 2000.

Ryrie, Charles C. Teologi Dasar 2. Yogyakarta: ANDI, 2006.Penias, Weslley. Catatan Kuliah Teologi Perjanjian Baru. Makassar, STT Jaffray, 15 Mei 2008.

Simanjuntak, Julianto Mencintai Hingga Terluka. Tangerang: Layanan Konseling Keluarga dan Karir, 2006.

Slamet, Juli Soemirat Kesehatan Lingkungan. Yogyakarta: Gadjah Mada University Press, 2002.

Soedarmo, R. Ikhtisar Dogmatika. Jakarta: BPK Gunung Mulia, 1985.

Stott, Jhon. Isu-Isu Global. Jakarta: Yayasan Komunikasi Bina Kasih / OMF, 2005.

Tappang, Elvi. Karya ilmiah: Konsep Kekayaan Kerdasarkan 2 Korintus Pasal 8 9 dan Aplikasinya Bagi Orang Kristen. Makassar: STTJ, 2007.

Tu'u, Tulus. Kuasa Bersyukur. Bandung: Kalam Hidup, 1998.

Tu’u, Tulus. Makna Penderitaan. Bandung: Kalam Hidup, 1993.

\section{Wawancara}

Penias, Weslley. Percakapan telepon dengan penulis, 24 Mei 2008.

Suryanto. Percakapan telepon dengan penulis, 26 April 2008. 